\title{
RESEARCH
}

Open Access

\section{Pharmacokinetic analysis of new synthetic antimalarial $\mathrm{N}-251$}

\author{
Kazuaki Okada', Akira Sato ${ }^{1,2}$, Akiko Hiramoto', Rena Isogawa ${ }^{1}$, Yuji Kurosaki ${ }^{3}$, Kazutaka Higaki ${ }^{4^{*}}$, Shin-Ichi Miyoshi ${ }^{5}$,
} Kyung-Soo Chang ${ }^{6}$ and Hye-Sook Kim ${ }^{1 *}$ (D)

\begin{abstract}
Background: With the emergence and growing number of drug-resistant Plasmodium falciparum, a new drug for malaria control must be urgently developed. The new antimalarial synthetic compound N-251 was recently discovered. As an endoperoxide structure in the body, the compound shows high antimalarial activity and curative effects. We performed a pharmacokinetic (PK) analysis of $\mathrm{N}-251$ under various conditions using mice to understand the inhibitory effect of $\mathrm{N}-251$ in parasite-infected mice.
\end{abstract}

Results: PK study of N-251 after intravenous and oral administration in mice showed plasma concentration of N-251 was decreased drastically by intravenous route. $C_{\max }$ was reached in $2 \mathrm{~h}$ after oral administration of $\mathrm{N}-251$, and the level decreased to a level similar to that obtained after intravenous administration. The area under the curves (AUCs) of the plasma concentration of $\mathrm{N}-251$ increased dose-proportionally in both administrations, and bioavailability $(F)$ was approximately $23 \%$. Additionally, $T_{\max ,} C_{\max ,}$ AUC, and $F$ increased in fasted mice compared to normal-fed mice after the administration of $\mathrm{N}-251$, indicating the influence of diet on the absorption kinetics of $\mathrm{N}-251$. Furthermore, in parasiteinfected fasted mice, the plasma concentration-time profile of $\mathrm{N}-251$ was similar to that in normal-fasted mice. Based on the PK parameters of single oral administration of N-251, we investigated the effect of multiple oral doses of N-251 (68 $\mathrm{mg} / \mathrm{kg}$ three times per day for 2 days) in normal-fed mice. The plasma concentration of N-251 was between 10 and 1000 $\mathrm{ng} / \mathrm{mL}$. The simulation curve calculated based on the PK parameters obtained from the single-dose study well described the plasma concentrations after multiple oral dosing, indicating that $\mathrm{N}-251$ did not accumulate in the mice. Multiple oral administrations of $\mathrm{N}-251$ in mice were required to completely eliminate parasites without accumulation of N-251.

Conclusions: $\mathrm{N}-251$ has been selected as a potent antimalarial candidate. We found that $\mathrm{N}-251$ showed short half-life in plasma, and AUCs increased proportionally to dose. With multiple doses of N-251, the plasma level of N-251 was greater than $10 \mathrm{ng} / \mathrm{mL}$ in normal-fed mice, and accumulation of $\mathrm{N}-251$ was not observed; however, multiple treatments with $\mathrm{N}$ 251 are required for the complete cure of parasite-infected mice. Determining the appropriate dosage was an important step in the clinical applications of $\mathrm{N}-251$.

Keywords: Synthetic endoperoxide, 6-(1,2,6,7-tetraoxaspiro [7.11] nonadec-4-yl)hexan-1-ol (N-251), Pharmacokinetic (PK) study, Bioavailability (F), Antimalarial medicine

\footnotetext{
* Correspondence: higaki@okayama-u.ac.jp; hskim@cc.okayama-u.ac.jp

${ }^{4}$ Department of Pharmaceutics, Faculty of Pharmaceutical Sciences, Okayama

University, 1-1-1 Tsushima-Naka, Kita-Ku, Okayama, Okayama 700-8530, Japan

${ }^{1}$ Division of International Infectious Diseases Control, Faculty of

Pharmaceutical Sciences, Okayama University, 1-1-1 Tsushima-Naka, Kita-Ku,

Okayama, Okayama 700-8530, Japan

Full list of author information is available at the end of the article
}

(c) The Author(s). 2019 Open Access This article is distributed under the terms of the Creative Commons Attribution 4.0 International License (http://creativecommons.org/licenses/by/4.0/), which permits unrestricted use, distribution, and reproduction in any medium, provided you give appropriate credit to the original author(s) and the source, provide a link to the Creative Commons license, and indicate if changes were made. The Creative Commons Public Domain Dedication waiver (http://creativecommons.org/publicdomain/zero/1.0/) applies to the data made available in this article, unless otherwise stated. 


\section{Background}

Malaria is a serious infectious disease caused by Plasmodium parasites mainly in tropical and subtropical regions. More than 219 million individuals have been infected with malaria parasites, and 435,000 deaths have been reported (WHO World Malaria Report 2018). Unfortunately, the resistant of Plasmodium falciparum to commonly used antimalarials is widespread [1, 2]. Since 1979, artemisinin has been isolated from the Chinese herb Artemisia annua and has been used to treat P. falciparum malaria [3, 4]. Currently, artemisinin-based combination therapies (ACT) are recommended by the WHO as first-line treatments of $P$. falciparum malaria; however, the emergence of parasites resistant to ACT in the area near the Thai-Cambodian border has been reported [5-8]. This confirms the need for the urgent development of new antimalarial drugs that are effective against such resistant parasites.

The endoperoxide structure of artemisinin is unique and is known to exhibit antimalarial activity [9]. In 2001, we synthesized several endoperoxide derivatives $[10,11]$. We found that 6-(1,2,6,7-tetraoxaspiro [7.11] nonadec-4-yl) hexan-1-ol (N-251) (Fig. 1a) had strong antimalarial activity against $P$. falciparum in human erythrocytes cultured in vitro and $P$. berghei in mice in vivo [12]. In the analysis of antimalarial mechanisms of N-251, P. falciparum endoreticulum-resident calcium-binding protein (PfERC) was found to be a possible candidate of the compound [13] that specifically inhibits trophozoite parasites [14]. Although the functions of PfERC are not yet known as its location is believed to be localized in the endoplasmic reticulum [15], this protein may have an important role in the development of parasites.

Pharmacokinetics in animal studies is required to forward the development of N-251, which is a drug that can be of practical use. Although we have already started the additional study about the improvement of the bioavailability $(F)$ of N-251 in non-infected rats [16], a pharmacokinetic (PK) analysis was performed under various conditions in mice, which included dose dependency, influence of diet, parasite infection, and number of administrations. In addition, the appropriate administration schedule for achieving the complete curative effect of N-251 against $P$. berghei in mice has already been determined [12]. By determining the PK parameters in this study, the appropriate administration schedules of $\mathrm{N}-251$ for achieving drug efficacy without causing side effects can be confirmed.

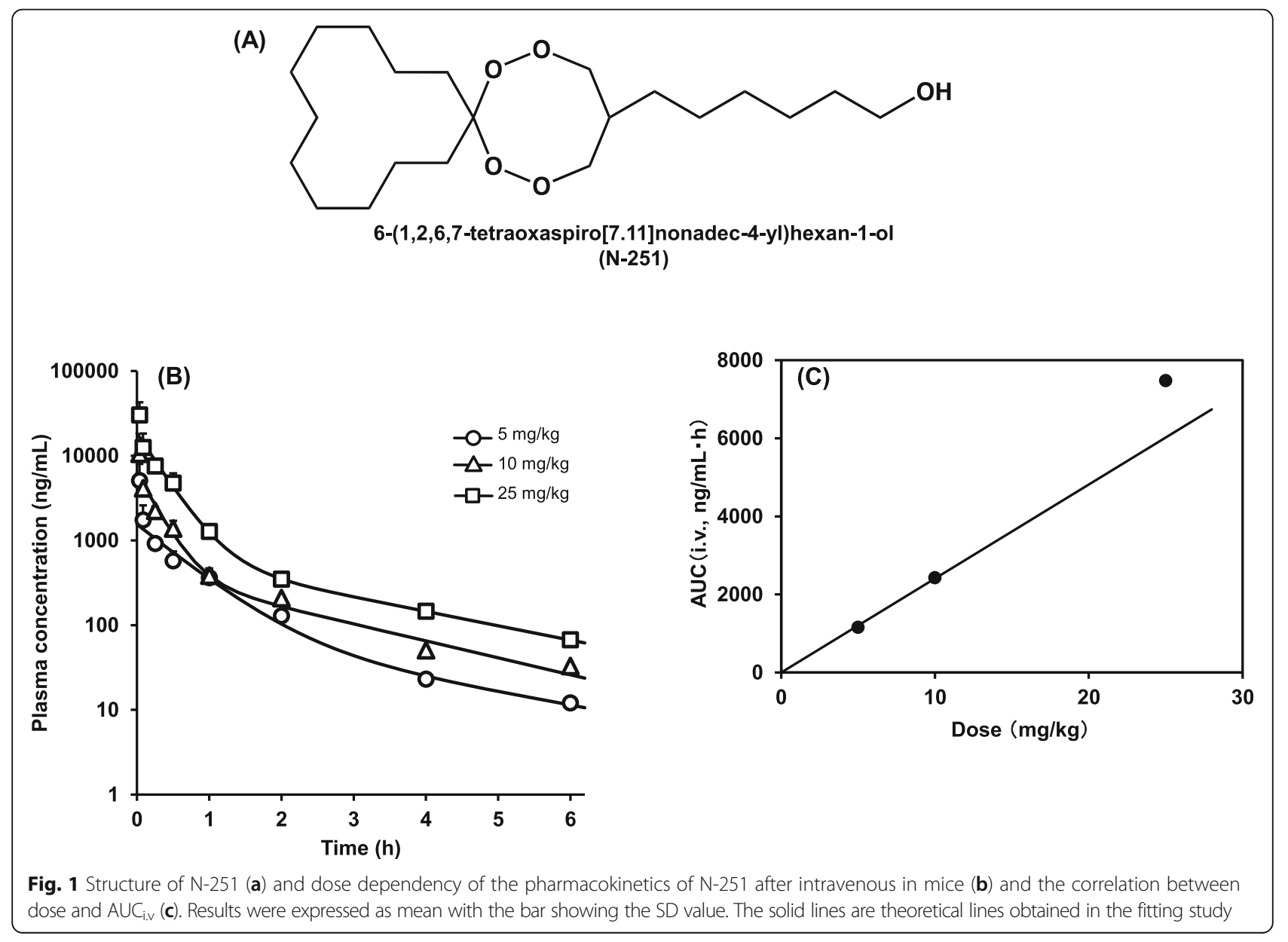




\section{Methods}

\section{Materials and preparation of $\mathrm{N}-251$ solution}

N-251 was synthesized, as described previously [12]. Cremophor EL was purchased from Sigma Chemical Co. (St. Louis, MO, USA), and olive oil was obtained from Wako (Osaka, Japan). All other chemicals and reagents were analytical grade commercial products. Various doses of N251 were administered as solutions to the groups of mice (six in each group) either orally (p.o., as solution in olive oil) or intravenously (i.v., as solution in 10\% ethanol, 10\% Chremophore $^{\circledast}$ EL, and 80\% saline (10:10:80 [v/v/v]).

\section{Animals}

Male ICR mice (5 weeks old) weighing 25-30 g (Charles River Laboratories Japan, Yokohama, Japan) maintained at $25^{\circ} \mathrm{C}$ and $55 \%$ humidity were allowed free access to standard laboratory chow (Clea Japan, Tokyo) and water. They were fasted for $24 \mathrm{~h}$ prior to and during the experiment but were allowed free access to water. Our study was carried out in accordance with the Guidelines for Laboratory Animals of Okayama University (OKU-2016150).

\section{$P$. berghei parasites}

P. berghei (NK65 strain) parasites were maintained by weekly passage of $1 \times 10^{6}$ infected red blood cells in a healthy mouse via i.v. infusion, and parasite-infected mice were used for the rodent malaria parasites in the study.

\section{Preparation of plasma samples and analytical method}

Blood samples were immediately centrifuged at $945 \mathrm{~g}$ $\left(4{ }^{\circ} \mathrm{C}, 10 \mathrm{~min}\right)$ to make plasma samples. To get $\mathrm{N}-251$ from plasma samples, we used acetonitrile as solvent. A total of $300 \mu \mathrm{L}$ acetonitrile was added to $100 \mu \mathrm{L}$ plasma samples and vortexed for $10 \mathrm{~s}$, and supernatant was obtained after centrifugation at $3259 g\left(4{ }^{\circ} \mathrm{C}, 10 \mathrm{~min}\right)$. Quantitative analysis of $\mathrm{N}-251$ was performed, as previously described [16]. Mouse plasma spiked with N-251 was prepared and analyzed using the same methods as standard curve of N-251.

\section{PK analysis after i.v. and p.o. administration of $\mathrm{N}-251$ in fasted mice}

We used healthy 5-week-old ICR male mice that were subjected to overnight fasting since the night a day before the test. To analyze N-251 after i.v. administration, doses of 25,10 , and $5 \mathrm{mg} / \mathrm{kg}$ were used for each group. The blood sample was collected at 2, 5, 15, and $30 \mathrm{~min}$ as well as 1, 2, 4, and $6 \mathrm{~h}$ post-dose, and a single blood sample was collected from a single mouse. Preparation of plasma samples of N-251 was described in the "Methods" section. Data were expressed as mean $(n=6)$ \pm standard deviation (SD). Plasma concentration-time profiles after i.v. administration were fitted to a twocompartment model using the non-linear least-squares regression program MULTI [17]. Plasma concentration (Cp) was expressed using the following equation:

$$
\mathrm{Cp}=A \cdot \operatorname{EXP}(-\alpha \cdot t)+B \cdot \operatorname{EXP}(-\beta \cdot t)
$$

where $\mathrm{A}$ and $\mathrm{B}$ are $\mathrm{D} \cdot\left(\alpha-\mathrm{k}_{21}\right) / \mathrm{Vd}_{1} /(\alpha-\beta)$ and $\mathrm{D} \cdot\left(\mathrm{k}_{21}\right.$ $-\beta) / \mathrm{Vd}_{1} /(\alpha-\beta)$, respectively. $\mathrm{D}, \mathrm{Vd}_{1}$, and $\mathrm{k}_{21}$ are the dose, apparent distribution volume of central compartment, and distribution rate constant from the peripheral to central compartment, respectively, and $\alpha$ and $\beta$ represent the slopes of $\alpha$ and $\beta$ phases of $\log C p$, respectively. $\mathrm{PK}$ parameters were calculated as follows: $\mathrm{AUC}=A$ / $\alpha+\mathrm{B} / \beta$; total body clearance, $\mathrm{CL}_{\text {total }}=\mathrm{D} / \mathrm{AUC}$; elimination rate constant, $\mathrm{k}_{\mathrm{el}}=(\mathrm{A} \beta+\mathrm{B} \alpha) /(\mathrm{A}+\mathrm{B})$; apparent distribution volume of peripheral compartment, $\mathrm{Vd}_{2}=\mathrm{k}_{12} /$ $\mathrm{k}_{21} \cdot \mathrm{Vd}_{1}$; distribution volume at steady state, $\mathrm{Vd}_{\mathrm{ss}}=\mathrm{Vd}_{1}+$ $\mathrm{Vd}_{2}$; and mean residence time $(\mathrm{MRT})=\left(\mathrm{k}_{12}+\mathrm{k}_{21}\right) /$ $\left(\mathrm{k}_{\mathrm{el}} \cdot \mathrm{k}_{21}\right)$.

To analyze the absorption kinetics of N-251, it was orally administered to fasted mice with dose of 210 , 100, 68, 50, and $30 \mathrm{mg} / \mathrm{kg}$. Blood sample was collected at 15 and $30 \mathrm{~min}$ as well as 1, 1.5, 2, 3, 4, and $6 \mathrm{~h}$ post-dose. Data were expressed as the mean $(n=6) \pm$ SD. AUC and MRT after p.o. administration in fasting mice were calculated based on the trapezoidal rule. $F$ was calculated with an AUC of $10 \mathrm{mg} / \mathrm{kg}$ of i.v. dose. The highest observed concentration was used as $C_{\max }$, and the time for $C_{\max }$ was defined as $T_{\max }$.

\section{Effects of food and parasite infection on the absorption behavior of $\mathrm{N}-251$ after p.o. administration in mice}

Normal-fasted and normal-fed mice were used for the analysis. Parasite-infected mice were prepared before the analysis, and a $0.61 \%$ infection rate in $P$. bergheiinfected mice under fasting condition was used. The single p.o. dose of $\mathrm{N}-251$ was $68 \mathrm{mg} / \mathrm{kg}$. Blood sample was collected 15, 30, and $45 \mathrm{~min}$ as well as 1, 1.5, 2, 3 , 4, and $6 \mathrm{~h}$ post-dose. Data were expressed as mean with the bar indicating the SD value.

\section{Effect of multiple p.o. dosing on the plasma concentration-time profile of $\mathrm{N}-251$}

$\mathrm{N}-251$ was administered p.o. at a dose of $68 \mathrm{mg} / \mathrm{kg}$ every $8 \mathrm{~h}$ for 2 days in normal-fed mice. Blood sample was collected at 15,30 , and $45 \mathrm{~min}$ as well as $1,1.5$, $2,3,4,6,8,10,16,18,24,26,32,34,40,42,44,46$, and $48 \mathrm{~h}$ after administration. Data were expressed as mean $(n=6)$ with the bar indicating the $\mathrm{SD}$ value. Simulation of plasma concentration-time profile after multiple dosing was performed by utilizing the parameters obtained via fitting analysis for the plasma concentration-time curve after a single p.o. dose of $\mathrm{N}-251$ based on the two-compartment model with the 
first-order absorption process. The equation and parameters used for the simulation were as follows:

$$
\begin{aligned}
\mathrm{Cp} & =X \cdot \operatorname{EXP}\left(-k a \cdot\left(t-t_{\mathrm{lag}}\right)\right)+Y \cdot \operatorname{EXP}\left(-\alpha \cdot\left(t-t_{\text {lag }}\right)\right) \\
& +Z \cdot \operatorname{EXP}\left(-\beta \cdot\left(t-t_{\mathrm{lag}}\right)\right),
\end{aligned}
$$

where $\mathrm{ka}$ and $t_{\mathrm{lag}}$ are absorption rate constant and lag time, respectively, and $X, Y, Z, \alpha$, and $\beta$ are the hybrid parameters. Their values used for simulation were as follows: $\mathrm{X}=8422 \mathrm{ng} / \mathrm{mL} / \mathrm{kg}, \mathrm{ka}=0.845 \mathrm{~h}^{-1}, \mathrm{Y}=-8419 \mathrm{ng} /$ $\mathrm{mL} / \mathrm{kg}, \alpha=1.09 \mathrm{~h}^{-1} \mathrm{ng} / \mathrm{mL} / \mathrm{kg}, \mathrm{Z}=5.29 \mathrm{ng} / \mathrm{mL} / \mathrm{kg}, \beta=$ $1.06 \mathrm{~h}^{-1}$, and lag time $=0.330$.

\section{Results}

\section{PK analysis after i.v. and p.o. administration of $\mathrm{N}-251$ in} fasted mice

The plasma concentration of N-251 after i.v. administration is shown in Fig. 1b, and each parameter is presented in Table 1. As shown in Fig. 1b, the plasma concentration of N-251 decreased in a time-dependent manner. The clearances of the 5 and $10 \mathrm{mg} / \mathrm{kg}$ groups were 4.30 and $4.11 \mathrm{~L} / \mathrm{h} / \mathrm{kg}$, respectively, which had a similar degree. The clearance of the $25 \mathrm{mg} / \mathrm{kg}$ group was $3.35 \mathrm{~L} / \mathrm{h} /$ $\mathrm{kg}$. These data showed that the clearance is more likely to decrease with the increase in dose. However, the extent was not so large. By examining half-life, the drug may be immediately distributed from the central to the peripheral compartment as $T_{1 / 2 \alpha}$ was $0.18-0.429 \mathrm{~h}$ and $T_{1 / 2 \beta}$ was $1.50-1.99 \mathrm{~h}$ (data not shown in Table 1 ). This result indicates that N-251 was rapidly eliminated from the plasma. The distribution volume was as large as $2.88-4.85 \mathrm{~L} / \mathrm{kg}$, which reflected that $\mathrm{N}-251$ was a high fat-soluble compound. Figure $1 \mathrm{c}$ shows the correlation between $\mathrm{AUC}_{\text {i.v. }}$ and dose of $\mathrm{N}-251$, indicating that the elimination of $\mathrm{N}-251$ might be saturable at higher doses.

The graph of N-251 plasma concentration after p.o. administration was observed in Fig. 2a, and each parameter is presented in Table 2. To calculate for $F$, we referred to an AUC of $10 \mathrm{mg} / \mathrm{kg}$ of i.v. dose, which corresponded to the blood concentration range observed after p.o. administration. The $T_{\max }$ was $2 \mathrm{~h}$ in every group of dose. In Fig. $2 \mathrm{a}$ and b, both $C_{\max }$ and $\mathrm{AUC}_{\mathrm{po}}$ had a liner correlation between 30 and $100 \mathrm{mg} / \mathrm{kg}$, and $F$ was approximately 0.22 . However, the $F$ value increased to 0.2982 at $210 \mathrm{mg} / \mathrm{kg}$, indicating that the elimination process of N-251 would be saturated at high dose level.

\section{Effects of food and parasite infection on the absorption behavior of $\mathrm{N}-251$ after p.o. administration in mice} We examined the influence of diet on the p.o. absorption of $\mathrm{N}-251$ at a single dose of $68 \mathrm{mg} / \mathrm{kg}$ in $0.61 \%$ parasite-infected mice. Figure 3 shows the results, and Table 3 depicts each of the obtained parameter. The plasma concentration of $\mathrm{N}-251$ in normal-fasted and infected-fasted mice was quite similar, and the influence of parasite infection in mice was minimal. In contrast, the plasma concentration of N-251 in normal-fed mice was lower than that in normal-fasted mice, and the $T_{\max }$ increased at $1.5 \mathrm{~h}$ in normal-fed mice and $2 \mathrm{~h}$ in normalfasted mice. The $C_{\max }$ also decreased in normal-fed mice $(953 \mathrm{ng} / \mathrm{mL})$ compared with normal-fasted mice (1677 $\mathrm{ng} / \mathrm{mL}$ ). The $F$ values were also decreased in normal-fed mice compare with normal-fasted mice.

\section{Effect of multiple p.o. dosing on plasma concentration- time profile of $\mathrm{N}-251$}

We considered the plasma concentration that was maintained after the administration of $68 \mathrm{mg} / \mathrm{kg}$ p.o. of $\mathrm{N}$ 251 three times a day for 2 days in normal-fed mice. Figure 4 shows the measured values of plasma concentration after repeated administration (open circles). It was measured immediately before the administration and $2 \mathrm{~h}$ post-dose when the plasma concentration of N-251 was the lowest. The solid line represents the simulation curve calculated based on the absorption kinetics obtained after a single dose of N-251 at $68 \mathrm{mg} / \mathrm{kg}$. Results showed that minimal plasma concentration was more than $10 \mathrm{ng} / \mathrm{mL}$, except $8 \mathrm{~h}$ after the first administration. In addition, the maximal concentration of N-251 in mice did not increase during multiple dosing schedules, and the plasma profile was well described via a simple simulation based on the absorption kinetics obtained after a single p.o. dosing, indicating that multiple treatments of $\mathrm{N}-251$ are safe for parasite-infected mice after p.o. treatment from the view point of pharmacokinetics. In our previous study, the $\mathrm{EC}_{50}$ value of N-251 P. falciparum (FCR-3 strain) in vitro was $8.6 \mathrm{ng} / \mathrm{mL}$, which is equivalent to $2.3 \times 10^{-8} \mathrm{M}[12]$. The plasma level of $\mathrm{N}-251$ was

\begin{tabular}{|c|c|c|c|c|c|c|c|c|c|c|c|}
\hline \multirow{2}{*}{$\begin{array}{l}\text { Dose } \\
(\mathrm{mg} / \mathrm{kg})\end{array}$} & \multicolumn{11}{|c|}{ Pharmacokinetic parameters } \\
\hline & $\begin{array}{l}\mathrm{AUC}_{\mathrm{iv}} \\
(\mathrm{ng} / \mathrm{mL} \cdot \mathrm{h})\end{array}$ & $\begin{array}{l}\mathrm{CL}_{\text {total }} \\
(\mathrm{L} / \mathrm{h} / \mathrm{kg})\end{array}$ & $\begin{array}{l}k_{\mathrm{el}} \\
\left(\mathrm{h}^{-1}\right)\end{array}$ & $\begin{array}{l}\mathrm{Vd}_{1} \\
(\mathrm{~L} / \mathrm{kg})\end{array}$ & $\begin{array}{l}\mathrm{Vd}_{2} \\
(\mathrm{~L} / \mathrm{kg})\end{array}$ & $\begin{array}{l}\mathrm{Vd}_{\mathrm{ss}} \\
(\mathrm{L} / \mathrm{kg})\end{array}$ & $\mathrm{MRT}_{\mathrm{iv}}(\mathrm{h})$ & $A(\mathrm{ng} / \mathrm{mL})$ & $a\left(h^{-1}\right)$ & $B(\mathrm{ng} / \mathrm{mL})$ & $b\left(h^{-1}\right)$ \\
\hline 5 & 1161.50 & 4.30 & 1.33 & 3.23 & 1.62 & 4.85 & 1.12 & $1453.6 \pm 465.9$ & $1.62 \pm 0.70$ & $92.5 \pm 182.0$ & $0.35 \pm 0.37$ \\
\hline 10 & 2433.64 & 4.11 & 2.60 & 1.58 & 2.35 & 3.93 & 0.96 & $5922.7 \pm 1731.5$ & $3.84 \pm 1.23$ & $410.0 \pm 253.8$ & $0.46 \pm 0.15$ \\
\hline 25 & 7455.60 & 3.35 & 2.47 & 1.36 & 1.52 & 2.88 & 0.86 & $17,738.1 \pm 1700.0$ & $3.12 \pm 0.55$ & $690.4 \pm 341.6$ & $0.39 \pm 0.10$ \\
\hline
\end{tabular}

Table 1 Pharmacokinetic parameters of $\mathrm{N}-251$ after intravenous administration in mice

Pharmacokinetic parameters were calculated using the equations described in the "Methods" section. $A, B, a$ and $b$ are hybrid parameters in the equation describing the plasma concentration-time profile after intravenous administration, and they were expressed as SD 


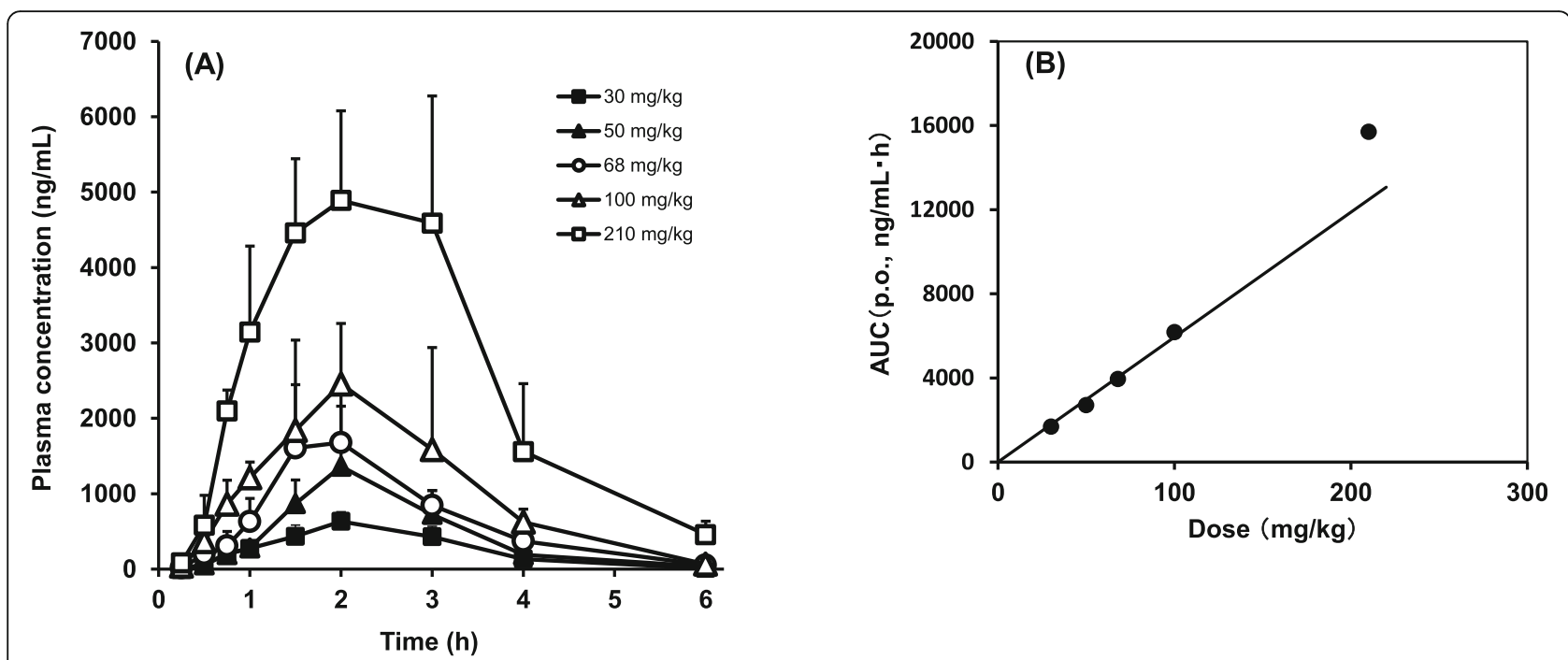

Fig. 2 Dose dependency of the pharmacokinetics of $\mathrm{N}-251$ after oral administration in mice (a) and correlation between dose and $A \cup C_{\text {p.o }}(\mathbf{b})$. Results were expressed as mean with the bar showing the SD value. The solid lines are theoretical lines obtained in the fitting study

between 10 and $1000 \mathrm{ng} / \mathrm{mL}$, indicating it can eliminate parasites and has curative effects in mice.

\section{Discussion}

The PK study of compounds for drug development of a drug used to treat malaria is an important step for further assessment in clinical trials. We discovered N-251 from random drug screening system for malaria in our university. N-251 and its related compounds had antimalarial activity and curative effects in $P$. falciparum in vitro and $P$. berghei in vivo in the mouse model in our previous reports [10-14]. Our antimalarial candidate N-251 has no UV absorption capability, and the standard HPLC system cannot be used. We must identify a new detection method using LC-MS/MS system. In 2015, we developed a detection method for N-251, and the first study of pharmacokinetics of N-251 formulation was reported [16]. N-251 was more lipophilic than griseofulvin $(\operatorname{cog} \mathrm{P}=2.88)$ [18] and the value of $\mathrm{N}-251 \operatorname{cog} \mathrm{P}$ was approximately 6.67 . The solubility of $\mathrm{N}-251$ in water was $7 \mu \mathrm{g} / \mathrm{mL}$, which was

Table 2 Pharmacokinetic parameters of N-251 after oral administration in mice

\begin{tabular}{|c|c|c|c|c|c|}
\hline \multirow{2}{*}{$\begin{array}{l}\text { Dose } \\
\text { (mg/ } \\
\mathrm{kg})\end{array}$} & \multicolumn{5}{|c|}{ Pharmacokinetic parameters } \\
\hline & $C_{\max }(\mathrm{ng} / \mathrm{mL})$ & $T_{\max }(\mathrm{h})$ & $A \cup C_{p o}(n g / m L \cdot h)$ & $F$ & $\mathrm{MRT}_{\mathrm{po}}(\mathrm{h})$ \\
\hline 30 & $633.67 \pm 128.70$ & 2 & 1574.04 & 0.2156 & 2.45 \\
\hline 50 & $1363.67 \pm 798.98$ & 2 & 2566.96 & 0.2110 & 2.49 \\
\hline 68 & $1677.33 \pm 811.23$ & 2 & 3768.25 & 0.2277 & 2.46 \\
\hline 100 & $2456.17 \pm 802.04$ & 2 & 5886.16 & 0.2419 & 2.46 \\
\hline 210 & $4890.00 \pm 1188.24$ & 2 & 15241.40 & 0.2982 & 2.74 \\
\hline
\end{tabular}

$C_{\max }$ with SD and $T_{\max }$ are observed values. The AUC and MRT were calculated from 0 to infinity using the trapezoidal rule. $F$ was calculated utilizing the AUC value of $2433.64 \mathrm{ng} / \mathrm{mL} \cdot \mathrm{h}$, after intravenous administration of $10 \mathrm{mg} / \mathrm{kg}$ similar to that of griseofulvin $(5-6 \mu \mathrm{g} / \mathrm{mL})$ [19]. In contrast, N-251 was dissolved in olive oil at $92 \mathrm{mg} / \mathrm{mL}$ and at $65 \mathrm{mg} / \mathrm{mL}$ in Cremophor EL [16]. Therefore, we used olive oil in the p.o. solution solvent and Cremophor ${ }^{\circ}$ ELbased i.v. solutions in the study.

In terms of the PK parameters of p.o. and i.v. N-251, $\mathrm{N}-251$ has a short half-life, and toxicity can be minimized by discontinuing the administration of $\mathrm{N}-251$. F in p.o. administration ranged from $21.1 \%$ to $29.8 \%$. Based on the PK study of artemisinin-based drugs, it had a short half-life (below $1 \mathrm{~h}$ ) and $F$ was approximately $8-10 \%$ [20]. Although it cannot be directly compared due to specific differences, N-251 is assumed to migrate to the systemic circulation at the same rate and to have the same efficacy as an artemisinin-based drug. Thus, N251 can be administered as an oral dosage form.

In the present study, it takes $2 \mathrm{~h}$ to reach the $C_{\max }$ after p.o. administration, and the $F$ is almost constant ranging from 30 to $100 \mathrm{mg} / \mathrm{kg}$. Total body clearance in i.v. administration of 5 and $10 \mathrm{mg} / \mathrm{kg}$ doses is quite similar. In 25 $\mathrm{mg} / \mathrm{kg}$ i.v. administration and $210 \mathrm{mg} / \mathrm{kg}$ p.o. administration (the largest dose in each dosage), clearances were more likely to decrease compared to those in other doses, which may be due to the saturation of N-251 elimination when the plasma concentration is relatively high.

We compared PK data between normal-fasted P. berghei-infected mice and normal-fasted mice, with a dose fixed at $68 \mathrm{mg} / \mathrm{kg}$. The plasma concentration of N-251 showed no differences between infected mice (infection rate of $0.61 \%$ ) and healthy mice. A higher amount of $\mathrm{N}$ 251 was distributed to infected erythrocytes than healthy erythrocytes. The plasma concentration was not affected because only $0.61 \%$ of erythrocytes are infected. Approximately $5 \%$ of infected mice used as the model of 


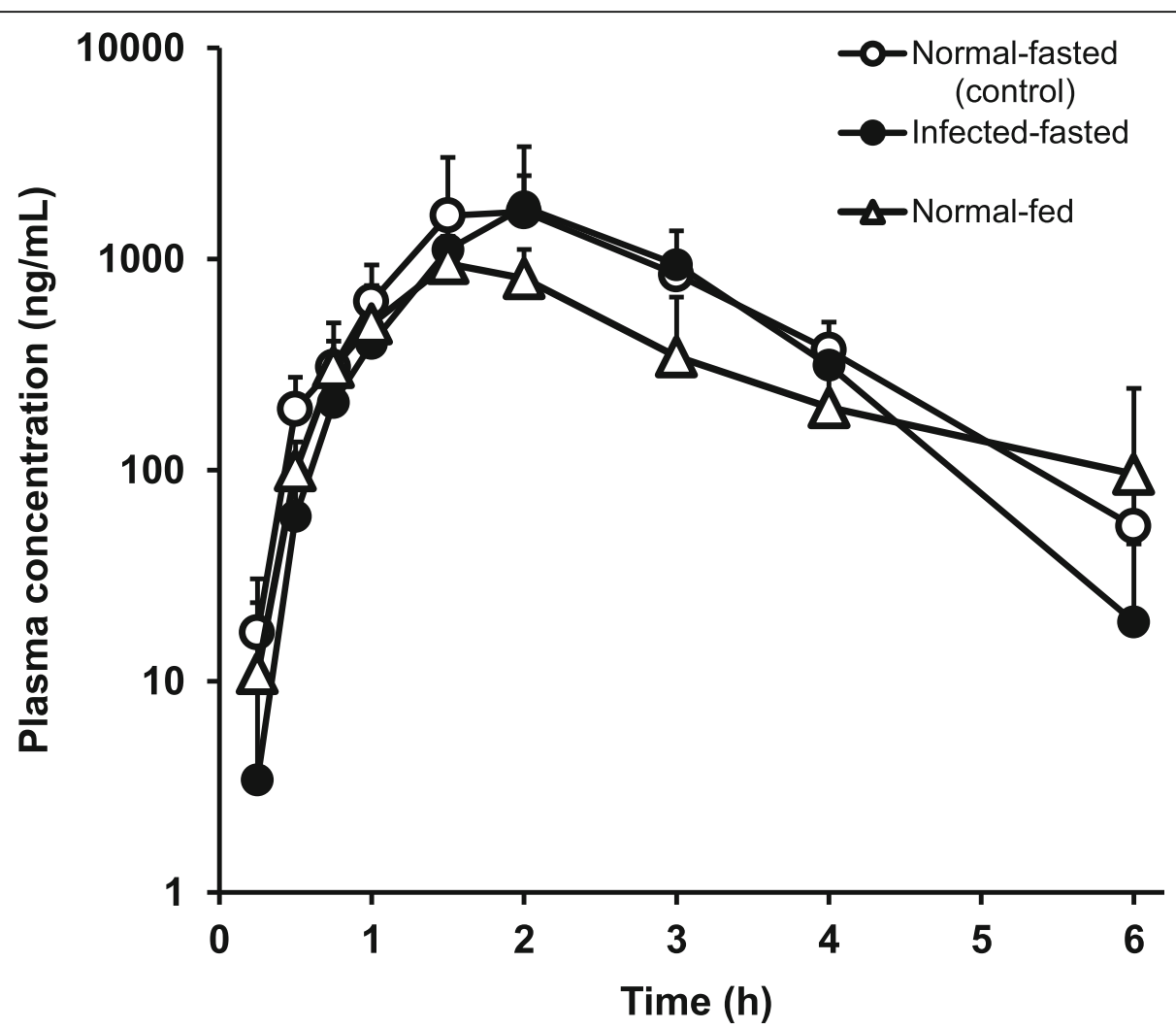

Fig. 3 Effects of food and parasite infection on the absorption behavior of N-251. The dose of N-251 was $68 \mathrm{mg} / \mathrm{kg}$. Results were expressed as mean with the bar showing the SD value

severe malaria also showed similar results (data not shown) . Based on these data, the PK data in healthy mice can be applied to the treatment design for infected mice. In terms of the influence of diet on pharmacokinetics, $T_{\max }$ was observed at an earlier time period $(1.5 \mathrm{~h})$, and the $C_{\max }$ decreased to $950 \mathrm{ng} / \mathrm{mL}$, which was $57 \%$ of normal-fasted mice. The AUC decreased to about $60 \%$ in fed mice. This result suggests that some interaction between $\mathrm{N}-251$ and diet suppressing the absorption might have occurred.

The PK analysis of repeated administration was based on the supposition of actual clinical experiments. We gained parameters based on the result of single p.o. administration in normal-fed mice. $C_{\min }$ was more than 10 $\mathrm{ng} / \mathrm{mL}$ except $8 \mathrm{~h}$ after the first administration. The PK and pharmacodynamic (PD) parameters are important in therapeutic drug monitoring for the proper use of drugs, such as antibacterial and anticancer drugs [21]. For antibacterial drugs, the PK/PD parameters that are correlated to drug effects are classified into three: $C_{\max } /$ minimum inhibitory concentration (MIC), AUC/MIC, and time above MIC. We applied this approach to N-251, and it was assumed that there was no difference in the drug effect of $\mathrm{N}-251$ between i.v. and p.o. administration based on the result of a 4-day suppressive test $\left(\mathrm{ED}_{50}\right.$ i.v. $22 \mathrm{mg} / \mathrm{kg}$; p.o. $15 \mathrm{mg} / \mathrm{kg}$ ) [11]. However, $F$ in p.o. administration in this experiment was $21.1-29.8 \%$, and the $C_{\max }$ and AUC were also lower in p.o. administration than in i.v. administration. Therefore, it was assumed that the drug effect did not correlate to either $C_{\max }$ or AUC. Elimination from the body between i.v. and p.o. administration with the short half-life of N-251 is less than $2 \mathrm{~h}$, and it was quickly eliminated from the plasma. In repeated administration, $C_{\min }$

Table 3 Effect of food and parasite infection on the oral absorption of N-251 in mice

\begin{tabular}{|c|c|c|c|c|c|}
\hline \multirow[t]{2}{*}{ Conditions } & \multicolumn{5}{|c|}{ Pharmacokinetic parameters } \\
\hline & $\overline{C_{\max }(\mathrm{ng} / \mathrm{mL})}$ & $T_{\max }(\mathrm{h})$ & $A \cup C_{p o}(n g / m L \cdot h)$ & $F$ & $\overline{M R T_{p o}(h)}$ \\
\hline Normal-fasted (control) & $1677.33 \pm 811.23$ & 2 & 3768.25 & 0.2277 & 2.46 \\
\hline Infected-fasted & $1767.17 \pm 1649.75$ & 2 & 3273.35 & 0.1978 & 2.45 \\
\hline Normal-fed & $952.50 \pm 332.49$ & 1.5 & 2282.17 & 0.1379 & 3.01 \\
\hline
\end{tabular}

The $C_{\max }$ with SD and $T_{\max }$ were the observed values. AUC and MRT were calculated from 0 to infinity using the trapezoidal rule. $F$ was calculated utilizing the AUC value of $2433.64 \mathrm{ng} / \mathrm{mL} \cdot \mathrm{h}$ after the intravenous administration of $10 \mathrm{mg} / \mathrm{kg}$ 


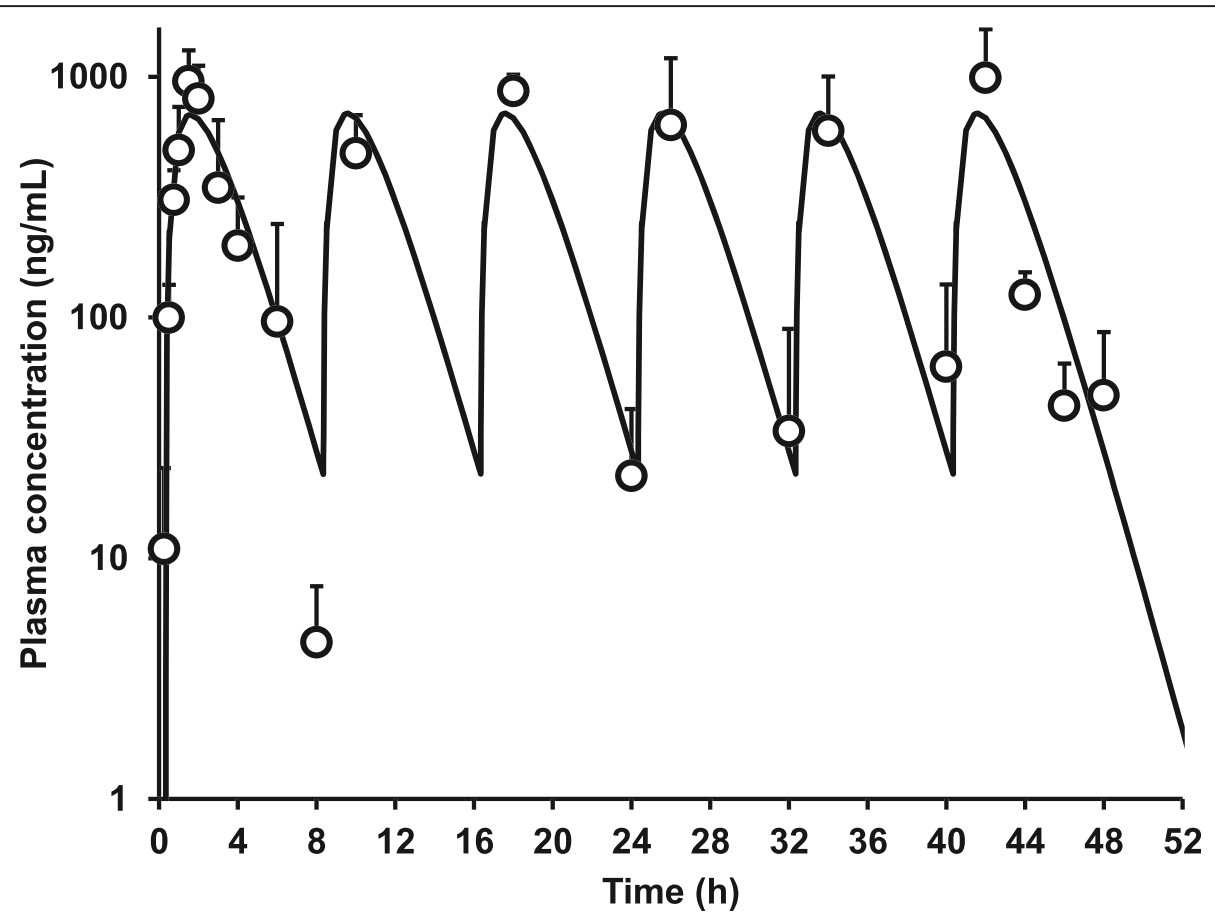

Fig. 4 Effect of multiple oral dosing on plasma concentration-time profile of $\mathrm{N}-251$. A dose of $68 \mathrm{mg} / \mathrm{kg}$ of N-251 was orally administered every 8 $h$ in normal-fed mice. Results were expressed as mean with the bar showing the SD value. The solid line was the simulation line calculated utilizing the equation shown in the "Methods" section as obtained in the fitting study for plasma concentration profile after a single oral administration

was more than $10 \mathrm{ng} / \mathrm{mL}$ except at $8 \mathrm{~h}$ after the first administration. Adequate plasma concentration was maintained after the second administration based on the $\mathrm{EC}_{50}$ value of $\mathrm{N}-251$ at $8.6 \mathrm{ng} / \mathrm{mL}\left(=2.3 \times 10^{-8} \mathrm{M}\right)$. In the case of a 68 $\mathrm{mg} / \mathrm{kg}$ dose administered three times a day for 3 days, the plasma concentration was maintained at more than $10 \mathrm{ng} /$ $\mathrm{mL}$ for $72 \mathrm{~h}$. This mean effective blood concentration was maintained for at least three times in the life cycles of rodent malaria parasites. Therefore, we administered N-251 following the treatment schedule with this condition in infected mice. As shown previously [12], malaria parasites decreased after $16 \mathrm{~h}$, and parasites were not observed in the bloodstream $36 \mathrm{~h}$ after treatment. No parasites were observed for 2 months after the last administration, and all mice were completely cured without recrudescence.

This research shows the PK data of N-251 via i.v. and p.o. administrations in mice, which is a cornerstone of the formulation and scaling up of research in the future. Furthermore, the drug effect is correlated to plasma concentration in N-251.

\section{Conclusion}

We carried out a PK study for the new antimalarial candidate N-251 after multiple p.o. administrations. N-251 had a short half-life in the plasma, and multiple p.o. administrations are required in parasite-infected mice. Interestingly, the plasma level of $\mathrm{N}-251$ is between 10 and $1000 \mathrm{ng} / \mathrm{mL}$, and it does not accumulate in the mice. Data indicated that
N-251 should be a safe drug for mammals, and a short half-life will require multiple treatments to completely eliminate the parasites without causing toxicity. This study first determined the PK parameters of N-251 to completely cure mice with malaria parasite infection.

\section{Abbreviations}

ACT: Artemisinin-based combination therapies; F: Bioavailability; i.v.: Intravenous; MIC: Minimum inhibitory concentration; N-251: 6-(1,2,6,7tetraoxaspiro [7.11] nonadec-4-yl)hexan-1-ol; p.o.: Per oral;

PD: Pharmacodynamic; PK: Pharmacokinetic

\section{Acknowledgements}

We thank Dr. Yusuke Wataya (Okayama University) and Dr. Masatomo Nojima (Osaka University) for helpful discussions. We would also like to thank Enago (www.enago.jp) for their English language editing service.

\section{Authors' contributions}

$\mathrm{KO}, \mathrm{KH}$, and HSK conceived and designed the study. KO, YK, and KSC performed the experiments. AS, AH, RI, and SM analyzed the data. All authors read and approved the final manuscript.

\section{Funding}

This study was partially supported by JSPS KAKENHI (18 K07086), Kobayashi International Scholarship Foundation (Kim, HS) and Japan Initiative for Global Research Network on Infectious Diseases (J-GRID) (JP18m0108002).

\section{Availability of data and materials} Not applicable

\section{Ethics approval and consent to participate}

The animal experiment in this study was approved by the Committee on the Animal Experiments of Okayama University (OKU-2016150), and all animal experiments were performed in the Animal Research Center at Tsushima 
Campus in accordance with the guidelines for laboratory animals of Okayama University.

\section{Consent for publication}

Not applicable

\section{Competing interests}

The authors declare that they have no competing interests.

\section{Author details}

'Division of International Infectious Diseases Control, Faculty of Pharmaceutical Sciences, Okayama University, 1-1-1 Tsushima-Naka, Kita-Ku, Okayama, Okayama 700-8530, Japan. ${ }^{2}$ Department of Biochemistry, Faculty of Pharmaceutical Sciences, Tokyo University of Science, 2641 Yamazaki, Noda, Chiba 278-8510, Japan. ${ }^{3}$ Department of Pharmaceutical Formulation Design, Faculty of Pharmaceutical Sciences, Okayama University, 1-1-1

Tsushima-Naka, Kita-Ku, Okayama, Okayama 700-8530, Japan. ${ }^{4}$ Department of Pharmaceutics, Faculty of Pharmaceutical Sciences, Okayama University, 1-1-1 Tsushima-Naka, Kita-Ku, Okayama, Okayama 700-8530, Japan. ${ }^{5}$ Department of Sanitary Microbiology, Faculty of Pharmaceutical Sciences, Okayama University, 1-1-1 Tsushima-Naka, Kita-Ku, Okayama, Okayama 700-8530, Japan. ${ }^{6}$ Department of Clinical Laboratory Science, College of Health Sciences, Catholic University of Pusan, Busan 46252, Republic of Korea.

Received: 11 March 2019 Accepted: 28 May 2019

Published online: 05 July 2019

\section{References}

1. Ridley RG. Medical need, scientific opportunity and the drive for antimalarial drugs. Nature. 2002;415:686-93.

2. Snow RW, Guerra CA, Noor AM, Myint HY, Hay SI. The global distribution of clinical episodes of Plasmodium falciparum malaria. Nature. 2005:434:214-7.

3. Klayman DL. Qinghaosu (artemisinin): an antimalarial drug from China. Science 1985:228:1049-55.

4. White NJ. Qinghaosu (artemisinin): the price of success. Science. 2008;320: 330-4.

5. Noedl H, Se Y, Schaecher K, Smith BL, Socheat D, Fukuda MM. Evidence of artemisinin-resistant malaria in western Cambodia. N Engl J Med. 2008;359:2619-20.

6. Dondorp AM, Nosten F, Yi P, Das D, Phyo AP, Tarning J, et al. Artemisinin resistance in Plasmodium falciparum malaria. N Engl J Med. 2009;361:455-67.

7. Dondorp AM, Fairhurst RM, Slutsker L, MacArthur JR, Breman JG, Guerin PJ, et al. The treat of artemisinin-resistant malaria. N Engl J Med. 2011;365:1073-5.

8. Phyo AP, Nkhoma S, Stepniewska K, Ashley EA, Nair S, McGready R, et al. Emergence of artemisinin-resistant malaria on the western border of Thailand: a longitudinal study. Lancet. 2012;379:1960-6.

9. Hartwig CL, Rosenthal AS, D'Angelo J, Griffin CE, Posner GH, Cooper RA. Accumulation of artemisinin trioxane derivatives within neutral lipids of Plasmodium falciparum malaria parasites is endoperoxide-dependent. Biochem Pharmacol. 2009;77:322-36.

10. Kim HS, Shibata Y, Wataya $Y$, Tsuchiya K, Masuyama A, Nojima M. Synthesis and antimalarial activity of cyclic peroxides, 1,2,4,5,7-pentoxocanes and 1,2,4,5-tetroxanes. J Med Chem. 1999:42:2604-9.

11. Kim HS, Nagai $Y$, Ono K, Begum K, Wataya $Y$, Hamada $Y$, et al. Synthesis and antimalarial activity of novel medium-sized 1,2,4,5-tetraoxacycloalkanes. J Med Chem. 2001;44:2357-61.

12. Sato A, Hiramoto A, Morita M, Matsumoto M, Komichi $Y$, Nakase $Y$, et al. Antimalarial activity of endoperoxide compound 6-(1,2,6,7-tetraoxaspiro [7. 11] nonadec-4-yl)hexan-1-ol. Parasitol Int. 2011:60:270-3.

13. Morita M, Sanai H, Hiramoto A, Sato A, Hiraoka O, Sakura T, et al. Plasmodium falciparum endoplasmic reticulum-resident calcium binding protein is a possible target of synthetic antimalarial endoperoxides, $\mathrm{N}-89$ and N-251. J Proteome Res. 2012;11:5704-11.

14. Morita M, Koyama T, Sanai H, Sato A, Hiramoto A, Masuayama A, et al. Stage specific activity of synthetic antimalarial endoperoxides, N-89 and N-251, against Plasmodium falciparum. Parasitol Int. 2015;64:113-7.

15. La GN, Hibbs AR, Riffkin C, Foley M, Tilley L. Identification of an endoplasmic reticulum-resident calcium-binding protein with multiple EF-hand motifs in asexual stage of Plasmodium falciparum. Mol Biochem Parasitol. 1997;89:283-93.

16. Imai C, Takahashi T, Kuramto M, Masuda K, Ogawara K, Sato A, et al. Improvement of oral bioavailability of n-251, a novel antimalarial drug, by increasing lymphatic transport with long-chain fatty acid-based selfnanoemulsifying drug delivery system. Pharm Res. 2015:32:2595-608.

17. Yamaoka K, Tanigawara Y, Nakagawa T, Uno T. A pharmacokinetic analysis program (MULTI) for microcomputer. J Pharmacobiodyn. 1981:4:879-85.

18. Fujioka Y, Kadono K, Fujie Y, Metsugi Y, Ogawara K, Higaki K, et al. Prediction of oral absorption of griseofulvin, a BCS class II drug, based on GITA model: utilization of a more suitable medium for in vitro dissolution study. J Control Release. 2008;352:36-43.

19. Fujioka Y, Metsugi Y, Ogawara K, Higaki K, Kimura T. Evaluation of in-vivo dissolution behavior and Gl transit of griseofulvin, a BCS class II drug. Int J Pharm. 2008:352:36-43.

20. Wei S, Ji H, Yang B, Ma L, Bei Z, Li X, et al. Impact of chrysosplenetin on the pharmacokinetics and anti-malarial efficacy of artemisinin against Plasmodium berghei as well as in vitro CYP450 enzymatic activities in rat liver microsome. Malar J. 2015;14:432-44.

21. Craing WA. Pharmacokinetic/pharmacodynamic parameters: rationale for antibacterial dosing of mice and men. Clin Infect Dis. 1998;26(1):1-10.

\section{Publisher's Note}

Springer Nature remains neutral with regard to jurisdictional claims in published maps and institutional affiliations.
Ready to submit your research? Choose BMC and benefit from:

- fast, convenient online submission

- thorough peer review by experienced researchers in your field

- rapid publication on acceptance

- support for research data, including large and complex data types

- gold Open Access which fosters wider collaboration and increased citations

- maximum visibility for your research: over $100 \mathrm{M}$ website views per year

At BMC, research is always in progress.

Learn more biomedcentral.com/submissions 